Article

\title{
From the Old New Republic to a Great Community: Insights and Contradictions in John Dewey's Public Pedagogy
}

\author{
James Anderson ${ }^{1,2}$ \\ ${ }^{1}$ Department of Media and Cultural Studies, University of California, Riverside, Riverside, CA 92521, USA; \\ E-Mail: jameska@ucr.edu \\ ${ }^{2}$ Communication Studies Department, Riverside City College, Riverside, CA 92506, USA; E-Mail: james.anderson@rccd.edu
}

Submitted: 22 September 2017 | Accepted: 4 December 2017 | Published: 9 February 2018

\begin{abstract}
This article draws from John Dewey's philosophy of education, ideas about democracy and pragmatist assumptions to explain how his articles for The New Republic functioned pedagogically. Taking media as a mode of public pedagogy, and drawing extensively from Dewey's Democracy and Education, as well as from his book The Public and its Problems, the article explores the relationships between communication, education and democracy using the expanded conceptions of all the aforementioned advanced by Dewey. Borrowing insights from Randolph Bourne, who used Dewey's own ideas to criticize his mentor's influence on intellectuals who supported US involvement in World War I, the analysis explores the contradictions within Dewey's public pedagogy. The article suggests Dewey's relevance as a public intellectual in the liberal-progressive press, his view of the State and some of his related presuppositions produced a tension in his thought, delimiting democratic possibilities while simultaneously pointing toward greater democratic potentials. The essay concludes by suggesting that learning from both Dewey and Bourne prompts us to get beyond the former's public/private dualism to realize what he called the "Great Community" by communicating and practicing the Commons.
\end{abstract}

\section{Keywords}

John Dewey; media; media history; public pedagogy; Randolph Bourne; The New Republic

\section{Issue}

This article is part of the issue "Media History and Democracy", edited by David W. Park (Lake Forest College, USA).

(C) 2018 by the author; licensee Cogitatio (Lisbon, Portugal). This article is licensed under a Creative Commons Attribution 4.0 International License (CC BY).

\section{Introduction}

The same year The New Republic (hereafter, TNR) published its first issue, John Dewey penned his first of many contributions for the weekly magazine. Dewey, the pragmatist philosopher perhaps best known for his philosophy of education, would go on to write well over 50 articles for TNR. To examine Dewey's role as a public intellectual, played out in the pages of TNR, this analysis borrows the notion of "public pedagogy", popularized in the last two decades by Henry Giroux (Sandlin, O'Malley, \& Burdick, 2011, p. 341). Public pedagogy is used here as a concept for understanding mediated culture as a site (or as sites) of informal, often under-acknowledged education (Giroux, 2004, 2008). A public pedagogy lens brings into focus how desires are mobilized and moral values are shaped (Giroux, 2000, p. 349). Public pedagogy serves here as a concept for critiquing forms of education occurring in and through mediated culture. Below I use the concept to critically understand Dewey's relevant work, found in TNR archive. Using ideas from Dewey's philosophical work-and drawing especially from Democracy and Education and The Public and its Problems-I examine how and why Dewey's contributions to TNR functioned pedagogically. I try to sketch the contours of the bounds within which Dewey's public pedagogy operated and which it helped reconstruct. To do so I relate Dewey's ideas to those of Randolph Bourne, who was mentored by Dewey at Columbia University and who worked as an editor for TNR for a time before becoming a prolific critic of his colleagues' support for World War I.

I hope to show how Dewey's relevance was in part related to his role as an influential thinker as well as to how he understood and communicated the role of the pub- 
lic in relation to education, democracy, community and especially the state. Dewey was not content to offer interpretations of the world; he applied his interpretations to problems and when possible tried to influence outcomes (Tiles, 1992, p. 2). Given that his written word had such influence, understanding the public pedagogy he propounded in the pages of a prominent journal of popular progressive opinion assumes added importance. Notably, Dewey also conceived of the public and the state as necessarily linked-he roughly conflated "the state" with "the public" (Dewey, 1927/1954, p. 21) in his major work on the subjects-and that conceptual knot appears to have produced a tension in his public pedagogy. Writers have posited Dewey's philosophy as commensurate with a social anarchism critical of arbitrarily justified authority and concentrated power, wielded by the state or otherwise (Chomsky, 2013, pp. 692-693; Mancias, 1982). What has not been explored is how Dewey's contributions to TNR reveal a pragmatism and idea of democracy fraught with potential for progress but bounded by his role as a public intellectual and by his related understanding of the state.

\section{Divergent Philosophies and Differing Ideas of Democracy}

Dewey's influence among educators became so strong within his lifetime that it prompted the formation of a society in his name (Tanner, 2015), while he was still contributing to TNR. His idea of education emphasized cultivation of a common understanding of means and ends necessary for intelligent control of the world we help comprise (Dewey, 1916/1997). As opposed to external control over others, education in this vein involves the freeing of individual capacities for flourishing directed toward social aims. Education in a democratic society implies providing "individuals a personal interest in social relationships and control" (p. 99) so that people can be active agents determining the direction of social change. Dewey's idea of education was intimately bound up with his idea of democracy. "Since a democratic society repudiates the principle of external authority", he wrote, "it must find a substitute in voluntary disposition and interest; these can be created only by education" ( $p$. 87). Moreover, "democracy is more than a form of government; it is primarily a mode of associated living, of conjoint communicated experience" (p. 87). Writing a decade later, Dewey (1927/1954) referred to democracy as "the idea of community life itself" (p. 148). It is "clear consciousness of a communal life, in all its implications", which "constitutes the idea of democracy" (p. 149).

Upon first inspection, Dewey's ideas stand in contrast to what one of his famous contemporaries wrote about democracy. Walter Lippmann, who was recruited by TNR's first editor-in-chief, Herbert Croly, to start as an editor at the magazine upon its inauguration, was comparatively sceptical about a democratic public. Others have highlighted the Dewey-Lippmann "debate" and emphasized its implications for the understanding of media and democracy (Crick, 2009; DeCesare, 2016; Dolber, 2017). Lippmann (1922/1997) believed news media are incapable of offering the truth to the public, insofar as that would entail bringing to light concealed facts, relating them and providing a picture of reality for people to use to act and participate in self-government (pp. 214-232). Lippmann's (1927/2017) “thesis" was that those constituting the public must remain "spectators of action" (p. 93), tasked merely with determining "the actor in a controversy who is most worthy of public support" (p. 120). Knowledgeable experts are needed, he thought, to manage people's affairs for them. Public constituents are a trampling "bewildered herd" ( $p$. 2 ), and the herd "must be put in its place", Lippmann (1927/2017) claimed. But Dewey (1927/1954), it is worth noting, also considered the existing public to be "bewildered" (p. 123), "inchoate" (p. 147), "confused and eclipsed" (p. 121). A tension within Dewey's philosophy, unpacked below, drew him closer to Lippmann in certain respects, even as they strongly diverged.

Dewey was arguably more concerned than his TNR colleague with how the public could "function democratically" (Dewey, 1927/1954, p. 147) and better recognize and communicate people's shared consequences. Dewey was an early proponent of what is sometimes called "public journalism" - reporting rooted in active civic involvement and committed to clearly communicating issues of social consequence (Perry, 2003). For the extant public to emerge out of eclipse required searching for (or creating) new "conditions", as Dewey put it, the characteristics of which bear striking resemblance to his ideas of education. An individual ought to have "a responsible share according to capacity in forming and directing the activities of the groups to which one belongs and in participating according to need in the values which the groups sustain"; creating conditions conducive to a democratic public implied "liberation of the potentialities of members of a group in harmony with the interest and goods which are common" (Dewey, 1927/1954, p. 147).

For Dewey, democracy could only be realized through education enabling individuals to play a role in consciously constituting collective life, and for that to occur education must be community based (Višňovský \& Zolcer, 2016, p. 58). Dewey understood democracy as a personal way of life and as a commitment to a community, to a social organization which helps individuals develop the capacity, and practice the ability, to criticize popular notions of what is right and good (Putnam, 2009). He envisioned democratic practice as providing the education necessary for the emergence of the "Great Community" (Dewey, 1927/1954), a consociation of selforganized individuals conscious of and each participating in decisions and actions shaping the consequences of the social life which in turn shapes them. Social psychologist Graham Wallas (1914) introduced a similar notion-the "Great Society" - the year TNR first hit the press, empha- 
sizing the greater nexus of connectivity created by industrialization and the expanded limits to communication characterizing a new social environment. Two years later, idealist philosopher Josiah Royce-who had three years earlier coined the related phrase, the "Beloved Community" (Royce, 1913/2001)-also popularized the notion of the "Great Community" in a book containing a title with the term (Royce, 1916), published the same year as Dewey's Democracy and Education. Both Royce and (later) Dewey took the "Great Community" as the ideal of a bonded humanity, but Dewey placed greater faith in the role of experimental inquiry and scientific advance as guiding its realization (Oppenheim, 2005). Pappas (2008) argued Dewey took the "Great Community" and democracy both as ideals and simultaneously as ethical instruments for negotiating the tensions and extremes located within our social experience; he took them as tools to tackle public problems to be assessed on the basis by which they enrich-and successfully address the problems of-present experience (pp. 217-259). As Bishop (2010) observed, Dewey believed the evolution of this "Great Community" required (among other conditions) freedom of inquiry and unrestricted production and dissemination of knowledge; member participation in achievements and struggles; cooperation among groups; and maintenance of shared means of communication (pp. 107-114). Notably, for Dewey, negative freedom of communication (i.e. freedom of the press from government censorship) was not enough (Pappas, 2008, p. 222). Democratic communication, for Dewey, necessarily entails education, understood broadly to include the teaching and learning taking place through culture. Dewey did not discuss in detail the number of individuals or the level of wealth necessary for a "Great Community" to thrive (Bishop, 2010, p. 114), although he was aware of the limits imposed by distance and scale, even if he never discussed how far we ought to extend our sense of self and the communal (Pappas, 2008, p. 229). Neither Dewey nor students of his philosophy interrogated fully, though, the limitations and obstacles inbuilt in the way humans have organized that extension, as with instruments like the nation-state. Also absent in the literature is a critique of the tensions within Dewey's role as a public intellectual, via his extensive TNR oeuvre, vis-à-vis his views on the relationships between values, democracy and the state. While there are early histories of TNR, some of which evaluate how values are shaped within the magazine and even some which highlight the magazine's relationship to education and Dewey's contributions (Nuechterlein, 1980; Peterson, 1999; Turner, 1983), little work has focused specifically on a constructive critique of Dewey's public pedagogy operating in TNR. What follows is an attempt to begin filling in those gaps.

\section{Education and/for Democracy in TNR}

At least 10 of the articles Dewey penned for TNR from the time the magazine was first established, in 1914, through
1916, the year Democracy and Education was published, were explicitly about education. Some of Dewey's contributions came in the form of a dialogue, insofar as that mode of education is possible through the press. In a reply to one critic, he argued against the kind of vocational education "which will 'adapt' workers to the existing industrial regime" - wryly remarking, "I am not sufficiently in love with the regime for that" - and he called instead for education "which would have as its supreme regard the development of such intelligent initiative, ingenuity and executive capacity as shall make workers, as far as may be, the masters of their own industrial fate" (Dewey, 1915a, p. 42). Those interested in practical education could "strive for a kind vocational education which will first alter the existing industrial system, and ultimately transform it" (p. 42). He warned of educational reforms which would rigidify the class system (Dewey, 1915b, p. 238). After a National Education Association meeting on education and culture, Dewey (1916a) defended the NEA aims of transmuting "a society built on an industry which is not yet humanized into a society which wields its knowledge and its industrial power in behalf of a democratic culture"-endeavors requiring "the courage of an inspired imagination" (p. 215). He claimed "the only test and justification of any form of political and economic society is its contribution to art and scienceto what may roundly be called culture. That America has not yet so justified itself is too obvious for even lament" (p. 216). Dewey's contributions connect public education to a formative culture and the relationship of both to an expansive practice of democracy, extended into the economic sphere, but also as part of the production of new political-community and aesthetic life.

Dewey also applauded experiments in education focused on the experimental method. Concordant with his later philosophical work (e.g. Dewey, 1930/2013, pp. $284,260,1939 / 1991$, pp. 51, 66), in TNR he called the scientific method "the spirit in which a social problem is to be approached" (Dewey, 1917a, p. 16). The public should, he suggested, become familiar with a method of education emphasizing experiment and discovery (p. 16). In one of many book reviews he wrote for TNR, Dewey (1918a) applauded Helen Marot, author of Creative Impulse in Industry, for stressing, as he put it, "the importance of such conditions and methods as will give each student-worker personal experience in the administrative control of the processes of production and marketing" (p. 23). Not only did he connect education to economic democracy in his articles. He also related those processes to the experimental method as a tool for understanding and mediating social consequences.

Expounding upon claims made by the American Association of University Professors, which he helped found, Dewey (1916b) claimed the "real question of academic freedom" had to do with the liberty of educators and students to engage in "serious thought on social difficulties and conflicts" (p. 16). Some two decades later, when he announced the formation of a committee to raise funds 
for a professor who staged a hunger strike to protest persecution of students at Polish universities and was subsequently fired from the City College of New York (Dewey, 1937a), he underscored for TNR readers that democratic freedoms imply education beyond academe.

\section{Lessons and Contradictions Regarding Democracy and the State}

The assumptions required for entrance into the range of debate in the progressive press appear to have made the breadth of Dewey's public pedagogy possible while simultaneously shipwrecking it on the shoals of the liberaldemocratic state. Despite chiding others for generalizations, Dewey (1927/1954) suggested, sans historical evidence, that once "indirect consequences are recognized and there is effort to regulate them, something having the traits of a state come into existence" (p. 12). When people "indirectly affected" by consequences of interconnected human activity "formed a public", Dewey presupposes, this presented "in embryonic form the traits that define a state, its agencies and officers" (p. 17). He cautioned against this "notion of 'The State"', which can draw "us imperceptibly into consideration of the logical relationship of various ideas to one another, and away from facts of human activity" (pp. 8-9). He warned against focusing on "causal agency instead of consequences" (p. 20) in an investigation of the state's emergence. Yet he drew conclusions from select consequences without sufficient focus on how people acted in relation to others to bring states into existence historically. Once people recognized "evil consequences", he abstractly avers, they then arrived at a "common interest" which they all decided, readers are told, required rules and thus selection of "guardians, interpreters, and, if need be, their executors" (p. 17).

Those under-examined presuppositions undergirded his understanding of the public and its potential. The tensions and tendencies played out in his TNR contributions. In an article about force, violence and law, Dewey (1916c) criticized those opposing the state and the use of police force, claiming that being "interested in ends and to have contempt for the means which alone secure them is the last stage of intellectual demoralization" (p. 296). The claim rests upon an untested assumption about what "alone secure" ends he presumed others desire. The assumption excludes alternative ideas about both means and ends, educating readers within the liberal-progressive frame. Dewey further criticized the peace movement-admonishing its "hostility to force" (p. 296) and reproaching pacifists for their failure to focus on organizing existing forces for more desirable and efficient ends. He rebuked peace activists for appealing to emotions without advocating for laws-or, perhaps for not also advocating for different social arrangements, although Dewey is somewhat ambiguous on that in the piece. Although he unpacked the appeal to ends as referring to actual results, not simply aspirations (p. 296), he placed the onus of responsibility not on those supporting militarized force pitting armies of states against each other, but instead on those opposing specific (not just any and all) uses of "force", a euphemism referring to the state-sponsored bullets and bombs already ripping open and burning human flesh throughout the European theatre.

The above bears resemblance to other commentaries Dewey authored for Croly's magazine which were later rebuked by the young writer Dewey once mentored. Randolph Bourne, who like Lippmann was one of the first recruited by Croly to join TNR, broke with the journal because of the publication's embrace of Woodrow Wilson's about-face away from neutrality toward intervention in World War I (Dos Passos, 1993/2000, p. 80; Westbrook, 2007, p. 105). The sentiment appears to have been mutual at the time, as "prowar progressives at TNR wanted nothing to do with him, of course" (Blake, 2014, p. 86).

Yet in earlier writing for TNR, Bourne (1915) commented favorably on Dewey's philosophy and character. He credited Dewey "with some of the wisest words ever set to paper", referred to Dewey's mind as "ultrademocratic", and called him "a prophet dressed in the clothes of a professor of logic" who "seems almost ashamed that he has seen the implications of democracy more clearly than anybody else in the great would-be democratic society about him, and so [has] been forced into the unwelcome task of teaching it" (p. 154). Bourne claimed that no one else "with such universally important things to say on almost every social and intellectual activity of the day, was ever published in forms more ingeniously contrived to thwart the interest of the prospective public" (p. 154).

Within two years Bourne would be critiquing Dewey, and his influence on progressive intellectuals, in The Seven Arts, a small and short-lived literary magazine. On Dewey's pragmatism-turned-realpolitik, Bourne (1917a) saw someone incredulously "more concerned over the excesses of the pacifists than over the excesses of military policy" (p. 689). Under-examined assumptions about using means at odds with democracy to achieve democratic results led Bourne (1917a) "to suspect that no programme is presented" by intellectuals under Dewey's sway-while lack of a pacifist program is chastised in TNR-“because they have none to present. This burrowing into war-technique hides the void where a democratic philosophy should be" (p. 694). Of special concern "is the relative ease with which the pragmatist intellectuals, with Professor Dewey at the head, have moved out their philosophy, bag and baggage, from education to war" (p. 692). Rather, Dewey and TNR turned, pragmatically the weekly commentaries implied, to a pedagogy of and for war. Bourne (1917b) satirized the sentiments expressed by TNR intellectuals: "War in the interests of democracy! This was almost the sum of their philosophy" (p. 142).

Dewey (1917b) elsewhere cautioned against efforts to silence anti-war activists, arguing that censorship and 
repression aimed at imposing uniformity of thought $-a$ "conscription of mind" (p. 129)-only fuel the flames. But in so doing he chided "the spectacle of ultra-socialists" and took issue with the "inefficacy of the conscription of mind as a means of promoting social solidarity" (p. 129), the sort of solidarity he called necessary "in war times" (p. 128). In another piece he distinguished the pacifistic American people from the "professional pacifists" (Dewey, 1917c, p. 358). He dismissed pacifist literature leading up to the war as "opportunistic-breathlessly, frantically so", deriding "the failure of the pacifist propaganda to determine finally the course of a nation which was converted to pacifism in advance", and lamenting "that the pacifists wasted rather than invested their potentialities when they turned so vigorously to opposing entrance into a war which was already all but universal" (p. 359).

Bourne offered two indirect rejoinders to that assertion, using parts of Dewey's own philosophy as tools for critique. If we had practiced Dewey's "revolutionary conceptions of what education means", as well as his "intellectual strategy" for such an education, the nation might have used its isolation to educate itself for democracy instead of engaging in war, which inevitably undermines democratic values (Bourne, 1917a, pp. 691, 698). And would Dewey's progeny "have turned their intellectual energies not to the problem of jockeying the nation into war, but to the problem of using our vast neutral power to attain democratic ends for ourselves and the rest of the world", avoiding militarism irreconcilable with democracy (in the sense Dewey once understood the idea, as ultimately incommensurate with the State), "They might have failed. The point is that they scarcely tried" (Bourne, 1917b, p. 136).

Known for making his mark between extremes (Hickman, 1990, p. 179), Dewey brought that tendency into the pages of TNR, pitting severe repression against antiwar socialism (and pacifistic Americans against peace activists) as opposing poles both deserving censure. But that liberal-progressive proclivity-occupying a supposed socio-political middle ground-like the emphasis on journalistic objectivity that arose with the advent of commercially-controlled media during Dewey's day, can result in false equivalencies and normalize arrangements which otherwise might be criticized as "extreme" were other criteria used to make the determination.

Echoing (or influencing) the ideas of TNR's editor-inchief Croly, who deemed US involvement in World War I a "rare opportunity", and a new "chance to focus the thought \& will of the country" (as cited in Levy, 2014, p. 249), Dewey told readers that war "must make" a "contribution" "to the creation of a united America" (Dewey, 1917 b, p. 130). He presupposed the benevolence of US state policy objectives when he lamented in TNR "that some of our intolerance at diversity of opinion and our willingness to suppress civil liberties of democracy in the name of loyalty to democracy is merely a part of our haste to get into the war effectively, a part of the rush of mobilization, which, thank heaven, had to be improvised because of our historic and established unmilitarism" (Dewey, 1917d, p. 18). He also referred to those in the US as "more highly socialized" (Dewey, 1918b, p. 232). His American exceptionalism as a mode of public pedagogy failed to teach about the history of international US military intervention and deployment of the military for domestic control. Echoing the American instrumentalism he popularized, the author called criticizing "the wickedness of war" and indulging "in asseverations of the obligations of states to act upon the basis of the most enlightened code" a "Pharisaic luxury", unless the critics would "fight for the establishment of a social organization which will make moral responsibilities and regulations a fact" (pp. 232-233). Dewey thereby dismissed vocal anti-war criticism (ignoring the mobilization that often accompanied it), excluding any consideration that organizing against international war could be part of that struggle for a more moral social organization. But he also levelled a tacit criticism regarding the morally questionable function of nation-states, implying states are at odds with forms of social organization in which real democratic sensibilities could be part and parcel.

In light of the support for war at TNR, the "philosophy upon which I had relied to carry us through", Bourne (1917a) lamented, "no longer works" (p. 690)-a wryly ironic condemnation of the popular Deweyan pragmatism, given its concern for what is functional. Presumably less than pleased with the criticism, Dewey surreptitiously forced Bourne off the editorial board of the Dial, another alternative weekly where he had been working (Blake, 2014, p. 86; Phelps, 1998, para. 3). While Dewey might not have fully grasped the lesson from the man he mentored at Columbia-the man who wrote "War is the health of the state" (Bourne, 1918/1998, p. 9) in an unfinished manuscript published soon after he died of influenza at 32-Dewey would later regret his full-fledged support for World War I, and TNR editors would go on to print a formal mea culpa regarding their support for it (Bennett \& Howlett, 2014, p. 29; Levy, 2014, p. 266).

\section{Conclusions and Consequences: Communicating the Commons}

Examination of the consequences of Dewey's insights and contradictions reveals some of the shortcomings in his public pedagogy, but perhaps that pedagogy provides lessons to be learned regarding how to act going forward. Central to Dewey's pedagogical project was the translation of philosophy into the language of the broader public. He tried to make the philosophies of Charles $\mathrm{S}$. Peirce and George H. Meade accessible to those outside his discipline through TNR (Dewey, 1936, 1937b). Likewise, he wrote an article in TNR about the need for a new individualism years before his book on the subject (Dewey, 1930/1999) came out, arguing democracy "denotes faith in individuality" and a "willing acceptance of the modifications of the established order entailed by 
the release of individualized capacities" (Dewey, 1922, p. 62). "Democracy will not be democracy until education", he added, promotes "release of distinctive aptitudes" (p. 63) of individuals across a variety of spheres.

In his work on the public, Dewey (1927/1954) posited that it is "only by distribution" that experimentally attained knowledge could "be either obtained or tested" (pp. 176-177). He went so far to refer to any "fact of community life" which isn't communicated so as to become a "common possession" a "contradiction in terms" (p. 177). He even equated the "formation of public opinion" with such mediated communication (p. 177). Functioning public opinion implies both "methods of investigation and reporting constantly at work" (p. 178). Indeed, while "news" denotes what just occurred in a way that contrasts with what was, individuals cannot derive meaning from it unless its mediation facilitates a consideration of possible "social consequences", which cannot be seriously considered "unless the new is placed in relation to the old, to what has happened and [has] been integrated into the course of events" (p. 180). Otherwise, sensationalism ensues. The sensation of the new becomes the reigning objective for journalism given how events are "so completely isolated from their connections" ( $p$. 180). The sensationalist prerogative of the press had become so hegemonic "that it may well sound ridiculous to say that", as Dewey had it, "a genuine social science would manifest its reality in the daily press" (p. 180), with scholarly articles and books providing tools for inquiry. Dewey's ethics held science and morals to be reconcilable (Welchman, 1995), and there is reason to believe Dewey would have wanted his TNR contributions to be a mode of scientific public pedagogy.

His rejection of the dualism between theory and action reveals itself in TNR as intrinsically tied to both his ideas about education and democratic control, which appear inextricable from his emphasis (epitomizing an important tension) on experimentation as crucial for knowledge and progress in a variety of human domains. After the US had entered World War I, Dewey (1918b) referred to the belief that international law expressed "not true but only moral law" as a "striking indication of the widespread absence of scientific understanding of morals" (p. 232), reaffirming his commitment to scientific explication of values and his belief in a bonded humanity, albeit one premised upon interlocking nationstates. "States", he claimed "are non-moral in their activities just because of the absence of an inclusive society which defines and establishes rights" (p. 232), thereby underscoring a contradictory assumption: States are insufficient when it comes to creating a moral order, but at least here Dewey assumes that they can be compatible with and do not militate against the morality of a Great Community. The untested assumption contributes to a public pedagogy overlooking ideas about experimenting with alternative institutions which could prove more supportive of such a community than the political state. Later, during the Depression, Dewey (1934) re- minded TNR readers of his position that "no genuine education is possible without active participation in actual conditions", pointing out again "that economic interests are the chief cause why this change in education is retarded and reflected" (p. 307). The great achievement of the physical sciences is that they showed action"namely, action that changes conditions that previously existed" (p. 307)-to be a necessary aspect of intelligence. Dewey (1930a) claimed the experimental attitude prompted adherence to "new truth" discovered, that science was "the foe of every belief that permits habit and wont to dominate", and that it would be "dangerous only for those who would maintain affairs in the existing social order unchanged because of lazy habit or self-interest" (p. 185). Responding to Nietzsche's notion that human beings now must create their own values, he told TNR readers when we start taking "science (including its application to the machine) for what it is", then "we shall begin to envisage it as a potential creator of new values and ends" (p. 186).

Yet Nietzsche (1918/2010) also understood the conditions prompting the "transvaluation of all values" (p. 149)-conditions arising from the ascendance of science and eclipse of religion-could have "catastrophic consequences", as one of Nietzsche's posthumous editors put it (Williams, 2001, p. xiii). Not for nothing, then, did Bourne (1917a) label his print media critique of Dewey Twilight of Idols, a title akin to Nietzsche's (1889/1997) Twilight of the Idols, save for the omitted article. Tellingly, Bourne cites Nietzsche approvingly in the final paragraph of his Seven Arts piece. Moreover, he remarked that progressive intellectuals in the wake of war "failed us as value-creators, even as value-emphasizers" (1917a, p. 700).

To be sure, the appeal and promise of Dewey's philosophy lies in part with his argument against acceptance of what exists based upon untested convention as well as the implications for understanding knowledge as tethered to intelligent action in the world. Yet questions remain. How are values to be tested (aside from perhaps democratically, insofar as that's possible)? How are tested values to be judged? What precepts, insights and means ought to be used in arriving at experimentally determined value judgments? How is the existing goodthe material for guidance and hope, Dewey suggeststo be identified as such? The problem announces itself in the last line from that same TNR article. In "accepting the corporate and industrial world in which we live, and thus by fulfilling the precondition for interaction with it, we", Dewey (1930a) avers, "who are also parts of the moving present, create ourselves as we create an unknown future" (p. 188). Why "accepting the corporate and industrial world" is a prerequisite for a proper remaking of the individual-and why the state should be presumed amenable for truly democratic community life-when other hitherto facts and habits are identified as outmoded-remains unclear. As Bourne (1917a) observed, "there was always that unhappy ambiguity in his 
doctrine as to just how values were created, and it became easier and easier to assume that just any growth was justified and almost any activity valuable so long as it achieved ends" (p. 697).

Tension and ambiguity notwithstanding, Dewey educated the TNR public, in ways hard to dismiss. Pitting the individual and social in opposition "distracts attention", he explained, from the crucial question of how the individual can "refind" himself "and what qualities the new individualism will exhibit" (Dewey, 1930b, p. 14). The insight parallels his previous call for the necessary restoration of "local communal life" lest the public be unable to "resolve its most urgent problem: to find and identify itself" (Dewey, 1927/1954, p. 216).

According to Hickman (1990), throughout his work Dewey demonstrated the "individual versus society" dilemma ceases to be an issue because there is "a problem of reconciling the extremes only if one has made the mistake of separating them in the first place" (p. 169). If you avoid taking the individual as a concept abstracted out from lived consociation with others-preconditions for actual human individuality-the dualism dissolves and the objective of greater freedom from the restrictions of nature and society is converted into the more productive desire for greater intimate relations with the world allowing for heightened capacity to understand and transform it (Hickman, 1990, p. 171).

Dewey, however, also advanced a dualism of his own. Dewey had no ontology of the state (Hickman, 1990, p. 172); he had none, though, because as suggested, he naturalized the state as an emergent property of the consequences of conjoint action extending beyond those persons directly responsible (Dewey, 1927/1954, pp. 24-27). The omission informed his qualified acceptance of the state as a tool for a democratic public. He explicitly stated his "thesis": that in the distinction between public and private "we find the key to the nature and office of the state" (Dewey, 1927/1954, p. 15). Therein lies the rub. In Hickman's (1990) words, "what is private and what is public are treated by Dewey as tools that may be brought to bear on problematic situations in ways that 'individual' and 'society', because of the ontological baggage they carry, cannot" (p. 170). For, Dewey, though, the notions of public and private are more than "functional concepts" (p. 170), as Hickman (1990) would have it. They are keys "to the nature and office of the state", if also "tools" for reconstructing the state. The characteristics, limitations and range of possible functions of tools make them useful for particular tasks and counterproductive when used for others. "Dewey is unequivocal in his view that the state is a technological artifact" (Hickman, 1990 , p. 173), a constructed and specific tool. It admittedly assumes various forms and functions from one society and epoch to the next, but it indisputably has certain defining characteristics (e.g. division between the public and private) which permit us to refer to the State. Yet even as he acceded to a state-centric framework, Dewey $(1927 / 1954)$ also referred to the "idea of democracy" as "a wider and fuller idea than can be exemplified in the state even at its best" (p. 143). Perhaps better tools than the state exist for practicing democracy and for creating the conditions needed for a Great Community to emerge.

Dewey (1916/1997) famously related the revelation and comprehension of previously unacknowledged connections to education and the communication of knowledge. To study and learn from Dewey prompts us then to follow Bourne and take the democratic idea of the Great Community further. "Bourne was the first American to" -40 years before Martin Luther King Jr.-borrow the "Beloved Community" ideal "from the work of the philosopher Josiah Royce and hold it up as the ultimate fulfilment of our national project" (McCarter, 2017, para. 8). One lesson to be learned from both could be the pragmatic overcoming of the private/public distinction. That dualism could be displaced by the "commons", what Linebaugh (2009) calls "the theory" - and, we could add, informed action- "that vests all property in the community and organizes labor for the common benefit of all" (p. 8). A precondition for such a community, then, involves communicating the commons so that individuals can consociate without coercion and together seek to better understand and control the consequences of their mediated social existence. The commons could then begin to displace technological artifacts, like the state, which unnecessarily encourage individuals to exercise control over each other. Future research could unravel the lessons, found in the public pedagogies of both Bourne and Dewey taken together, for translating such a democratic experiment into action.

\section{Acknowledgments}

The author thanks Nick Smaligo, Eli Kramer, Noah Springer, Phil Brewer and Larry Hickman for sharing ideas relevant to the research for, and writing of, this article.

\section{Conflict of Interests}

The author declares no conflict of interests.

\section{References}

Bennett, S. H., \& Howlett, C. F. (2014). Antiwar dissent and peace activism in World War I America: A documentary reader. Lincoln, NA: University of Nebraska Press.

Bishop, P. S. (2010). Dewey's pragmatism and the great community (Unpublished doctoral dissertation). University of South Florida, Tampa, FL.

Blake, C. N. (2014). War and the health of Randolph Bourne. Raritan, 34(1), 86-90.

Bourne, R. (1915, March 13). John Dewey's philosophy. New Republic, 2(19), 154-156.

Bourne, R. (1917a). Twilight of idols. Seven Arts, 2(6), 688-702. Retrieved from http://library.brown.edu/ pdfs/1349203543250004.pdf 
Bourne, R. (1917b). War and the intellectuals. Seven Arts, 2(2), 133-145. Retrieved from http://library.brown. edu/pdfs/1349194647703129.pdf

Bourne, R. (1998). The state. Tucson, AZ: Sharp Press. (Original work published 1918)

Chomsky, N. (2013). The Dewey lectures: What kind of creatures are we? Lecture III: What is the common good? The Journal of Philosophy, 110(12), 685-700.

Crick, N. (2009). The search for a purveyor of news: The Dewey/Lippmann debate in an Internet age. Critical Studies in Media Communication, 26(5), 480-497.

DeCesare, T. (2012). The Lippmann-Dewey 'debate' revisited: The problem of knowledge and the role of experts in modern democratic theory. Philosophical Studies in Education, 43, 106-116.

Dewey, J. (1915a, May 15). Education vs. trade-trainingDr. Dewey's reply. New Republic, 3(28), 42-43.

Dewey, J. (1915b, April 17). Splitting up the school system. New Republic, 2(24), 283-284.

Dewey, J. (1916a, July 1). American education and culture. New Republic, 7(87), 215-217.

Dewey, J. (1916b, May 6). The school and social preparedness. New Republic, 7(79), 15-16.

Dewey, J. (1916c, January 22). Force, violence and law. New Republic, 5(64), 295-297.

Dewey, J. (1917a, February 3). Experiment in education. New Republic, 10(118), 15-16.

Dewey, J. (1917b, September 1). Conscription of thought. New Republic, 12(148), 128-130.

Dewey, J. (1917c, July 28). The future of pacifism. New Republic, 11(143), 358-360.

Dewey, J. (1917d, November 3). In explanation of our lapse. New Republic, 13(157), 17-18.

Dewey, J. (1918a, November 2). Creative industry. New Republic, 17(209), 20-23.

Dewey, J. (1918b, March 23). Morals and the conducts of states. New Republic, 14(177), 232-234.

Dewey, J. (1922, December 13). Individuality and superiority. New Republic, 33(419), 9-11.

Dewey, J. (1930a, April 2). Individuality in our day. New Republic, 62(800), 184-188.

Dewey, J. (1930b, February 19). Toward a new individualism. New Republic, 62(794), 13-16.

Dewey, J. (1934, April 25). Intelligence and power. New Republic, 78(1012), 306-307.

Dewey, J. (1936, July 22). The work of George Mead. New Republic, 87(1129), 329-330.

Dewey, J. (1937a, March 31). Correspondence: Righting an academic wrong. New Republic, 90(1165), 241-242.

Dewey, J. (1937b, February 3). Collected papers of Charles Sanders Peirce. New Republic, 89(1157), 415-416.

Dewey, J. (1954). The public and its problems. Athens, OH: Shallow Press/Ohio University Press. (Original work published 1927)

Dewey, J. (1991). Experience, knowledge and value: A rejoinder. In J. A. Boydston (Ed.), John Dewey: The later works, 1925-1953: Volume 14: 1939-1941 (pp.
3-90). Carbondale, IL: Southern Illinois University Press. (Original work published 1939)

Dewey, J. (1997). Democracy and education: An introduction to the philosophy of education. New York, NY: The Free Press. (Original work published 1916)

Dewey, J. (1999). Individualism old and new. Amherst, NY: Prometheus Books. (Original work published 1930)

Dewey, J. (2013). The quest for certainty. New Delhi: Isha Books. (Original Work published 1930)

Dolber, B. (2017). Media and culture in the U.S. Jewish labor movement. Cham: Palgrave Macmillan.

Dos Passos, J. (2000). 1919: Volume two of the U.S.A. trilogy. New York, NY: Houghton Mifflin. (Original work published 1932)

Giroux, H. A. (2000). Public pedagogy as cultural politics: Stuart Hall and the 'crisis' of culture. Cultural Studies, 14(2), 341-360.

Giroux, H. A. (2004). Cultural studies, public pedagogy and the responsibility of intellectuals. Communication and Critical/Cultural Studies, 1(1), 59-79.

Giroux, H. A. (2008). Hollywood film as public pedagogy: Education in the crossfire. Afterimage, 35(5), 7-13.

Hickman, L. A. (1990). John Dewey's pragmatic technology. Bloomington, IN: Indiana University Press.

Levy, D. W. (2014). Herbert Croly of the New Republic: The life and thought of an American progressive. Princeton, NJ: Princeton University Press.

Linebaugh, P. (2009). The Magna Carta manifesto: Liberties and commons for all. Berkeley, CA: University of California Press.

Lippmann, W. (1997). Public opinion. New York, NY: Free Press Paperbacks. (Original work published 1922)

Lippmann, W. (2017). The phantom public. New York, NY: Routledge. (Original work published 1927)

Mancias, P. T. (1982). John Dewey: Anarchism and the political state. Transactions of the Charles S. Peirce Society, 18(2), 133-158.

McCarter, J. (2017, August 13). The critic who refuted Trump's world view-In 1916. New Yorker. Retrieved from https://www.newyorker.com/books/second$\mathrm{read} /$ the-critic-who-refuted-trumps-world-view-in1916

Nietzsche, F. (1997). Twilight of the idols (R. Polt, Trans.). Indianapolis, IN: Hackett Publishing Company. (Original work published 1889)

Nietzsche, F. (2010). The Anti-Christ (H. L. Mencken, Trans.). Auckland: The Floating Press. (Original work published 1918)

Nuechterlein, J. A. (1980). The dream of scientific liberalism: The New Republic and American progressive thought, 1914-1920. The Review of Politics, 42(2), 167-190.

Oppenheim, F. M. (2005). Reverence for the relations of life: Re-imagining pragmatism via Josiah Royce's interactions with Peirce, James, and Dewey. Notre Dame, IN: University of Notre Dame Press.

Pappas, G. (2008). John Dewey's ethics: Democracy as experience. Bloomington, IN: Indiana University Press. 
Perry, D. (2003). The roots of civic journalism: Darwin, Dewey, and Mead. Lanham, MD: University Press of America.

Peterson, M. D. (1999). Coming of age with the New Republic, 1938-1950. Columbia, MS: University of Missouri Press.

Phelps, C. (1998). Bourne yet again: Errors of genealogy. New Politics, 7(1). Retrieved from http://nova. wpunj.edu/newpolitics/issue25/phelps25.htm

Putnam, R. A. (2009). Democracy as a way of life. In G. Spadafora \& L. Hickman (Eds.), John Dewey's educational philosophy in international perspective: A new democracy for the twenty-first century (pp. 36-47). Carbondale, IL: Southern Illinois University Press.

Royce, J. (2001). The problem of Christianity. Washington, DC: The Catholic University of America Press. (Original work published 1913)

Royce, J. (1916). The hope of the great community. New York, NY: The Macmillan Company.

Sandlin, J. A., O'Malley, M. P., \& Burdick, J. (2011). Mapping the complexity of public pedagogy scholarship: 1894-2010. Review of Educational Research, 81(3), $338-375$.

\section{About the Author}

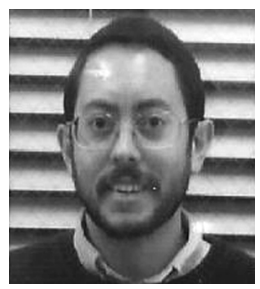

James Anderson is an adjunct professor working in Southern California. Like other contingent faculty, he has taught, and tries to pick up classes each term at, multiple colleges and universities. James is from Illinois. He earned a PhD in Mass Communication and Media Arts from Southern Illinois University Carbondale, a master's degree in Communication from the University of Illinois at Springfield and a bachelor's in kinesiology from the University of Illinois at Urbana-Champaign. He has worked as a freelance journalist for several online news outlets.
Tanner, D. (2015). Crusade for democracy: Progressive education at the crossroads. Albany, NY: State University of New York Press.

Tiles, J. E. (1992). John Dewey: Political theory and social practice. New York, NY: Routledge.

Turner, S. J. (1983). The new education in the New Republic magazine, 1914-1930 (Unpublished doctoral dissertation). University of Oklahoma, Norman, OK.

Višňovský, E., \& Zolcer, Š. (2016). Dewey's participatory educational democracy. Educational Theory, 66(1/2), 55-71.

Wallas, G. (1914). The great society: A psychological analysis. New York, NY: The Macmillan Company.

Welchman, J. (1995). Dewey's ethical thought. Ithaca, NY: Cornell University Press.

Westbrook, R. (2007). Bourne over Baghdad. Raritan, 27(1), 104-117.

Williams, B. (2001). Introduction. In F. Nietzsche, The gay science (J. Nauckhoff, Trans., pp. ix-xxii). Cambridge: Cambridge University Press. 